Sādhanā Vol. 27, Part 3, June 2002, pp. 375-382. () Printed in India

\title{
Knock characteristics of dual-fuel combustion in diesel engines using natural gas as primary fuel
}

\author{
O M I NWAFOR \\ Department of Mechanical Engineering, Federal University of Technology, \\ Owerri, Imo State, Nigeria
}

MS received 13 November 2001; revised 13 May 2002

\begin{abstract}
This paper investigates the combustion knock characteristics of diesel engines running on natural gas using pilot injection as means of initiating combustion. The diesel engines knock under normal operating conditions but the knock referred to in this paper is an objectionable one. In the dual-fuel combustion process we have the ignition stage followed by the combustion stage. There are three types of knock: diesel knock, spark knock and knock due to secondary ignition delay of the primary fuel (erratic knock). Several factors have been noted to feature in defining knock characteristics of dual-fuel engines that include ignition delay, pilot quantity, engine load and speed, turbulence and gas flow rate.
\end{abstract}

Keywords. Pressure and heat release diagrams; combustion knock; operating speed.

\section{Introduction}

Research work world-wide involving the use of natural gas in internal combustion (IC) engines has been intensified due to environmental concern and/or exhaustion of conventional fossil fuels (Karim \& Ali 1975). The renewable energy sources, natural gas, bio-derived gases and liquids appear to be greener alternative sources for internal combustion (IC) engines. The fuel system of a natural gas engine is some what different from that of the liquid fuel engine. Means for utilisation of natural gas in spark ignition (SI) engines are well established and documented whilst development efforts are still going on towards its use in compression ignition (CI) engines due to related problems. Natural gas has longer ignition delay and slower burning rates compared to diesel fuel operation (Nwafor \& Rice 1994). Again it has high self-ignition temperature (SIT) of about $704^{\circ} \mathrm{C}$, (Stephenson \& Raine 1980). It therefore, cannot be used in CI engines without a means of initiating combustion since the temperature attained at the end of compression stroke is relatively lower than the SIT of the gas. In the gas-fumigated dual-fuel engine, the primary fuel is mixed with air outside the cylinder before it is inducted into the cylinder. A mixture of gas and air is compressed during the compression stroke and before the end of the stroke, a pilot quantity of diesel fuel (depending on the operating conditions) is injected to initiate combustion. The combustion processes of dual-fuel engines lie between that of the CI and SI engines. The longer burning rate of the gas allows more time 
for heat transfer to the end gas resulting in a tendency to knock (Moore \& Mitchell 1955). In $\mathrm{CI}$ engines, knocking is due to combustion of premixed fuel and the degree of knock depends on the period of ignition delay Goodger 1980; Needham Doyle 1983 \& Heywood 1988. The present study was designed to investigate knock characteristics of dual-fuel engines using natural gas as primary fuel. The use of natural gas in CI engines involves an evolution of two stages of ignition and combustion processes resulting in three types of knock: diesel knock, spark knock and erratic knock due to spontaneous ignition of the primary fuel. The dualfuel engine knock was seen to depend on engine load and speed, combustion temperature, pilot fuel/gas ratio and turbulence in the cylinder. The operating conditions was improved by increasing pilot fuel and reducing the primary fuel.

\section{Experimental apparatus}

The specific type of engine used in this programme of work is the Petter model AC1 single cylinder, energy-cell diesel engine. It is an air-cooled, high speed, indirect-injection fourstroke engine. The energy cell consists of major and minor chambers which open into the main combustion chamber. The cell induces a secondary turbulence which aids complete combustion resulting from good mixing. The experimental system used for measuring engine performance characteristics is illustrated in figure 1. Measurement of combustion chamber pressure was obtained by installing a Kistler type 7063A, sensitivity 79 pc/bar, water-cooled

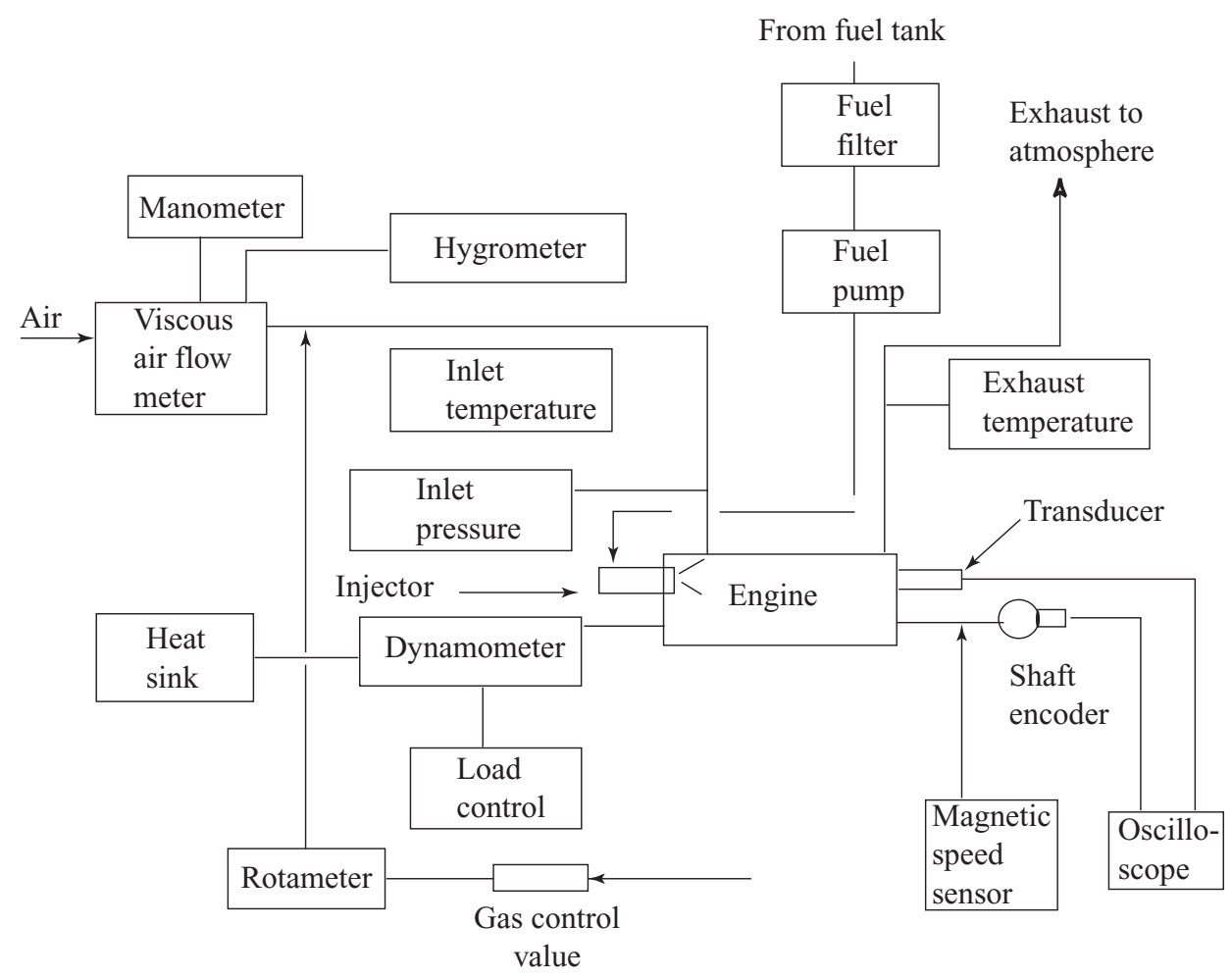

Figure 1. Illustration of system. 
piezo-electric pressure transducer into the air-cell of the combustion chamber. The cylinder pressure was displayed on a digital storage oscilloscope (Nicolet 4094) and stored in a diskette for later analysis of maximum rate of cylinder pressure rise. The hydrocarbon (HC) emissions were measured by a Rotork flame ionisation detector (FID) analyser model 523 with heated line system. $\mathrm{CO}$ and $\mathrm{CO}_{2}$ levels were monitored by an Oliver $\mathrm{K} 550$ infrared analyser.

\subsection{Natural gas typical composition and important parameters}

Typical composition of natural gas is: nitrogen $2.18 \%$, methane $92.69 \%$, ethane $3.43 \%$, carbon dioxide $0.52 \%$, propane $0.71 \%$, iso-butane $0.12 \%, N$-butane $0.15 \%$, pentane $0.09 \%$ and hexane $0.11 \%$.

Other important parameters are:

Gross calorific value

$=38.59 \mathrm{MJ} / \mathrm{m}^{3}$

Net calorific value

$=34.83 \mathrm{MJ} / \mathrm{m}^{3}$

Gross Wobbe number

$=49.81 \mathrm{MJ} / \mathrm{m}^{3}$

Stoichiometric A/F ratio

$=16.65: 1$

Net calorific value of diesel fuel $=42.70 \mathrm{MJ} / \mathrm{kg}$

Relative density of diesel fuel $=0.844$

\subsection{Engine data}

These are the specifications of the engine used. Bore $=76.20 \mathrm{~mm}$, stroke $=66.67 \mathrm{~mm}$, engine capacity $=304 \mathrm{ml}$, compression ratio $=17: 1$, fuel injection release pressure $=$ 18.3 $\mathrm{MN} / \mathrm{m}^{2}$, fuel injection timing $=30^{\circ} \mathrm{BTDC}$ (before top dead centre).

\section{Test results}

\subsection{Pressure and heat release diagrams}

Figures 2 and 3 show typical pressure crank angle and heat release diagrams of dual-fuel operation. The gas-fumigated dual-fuel engine has combustion characteristics which lie between

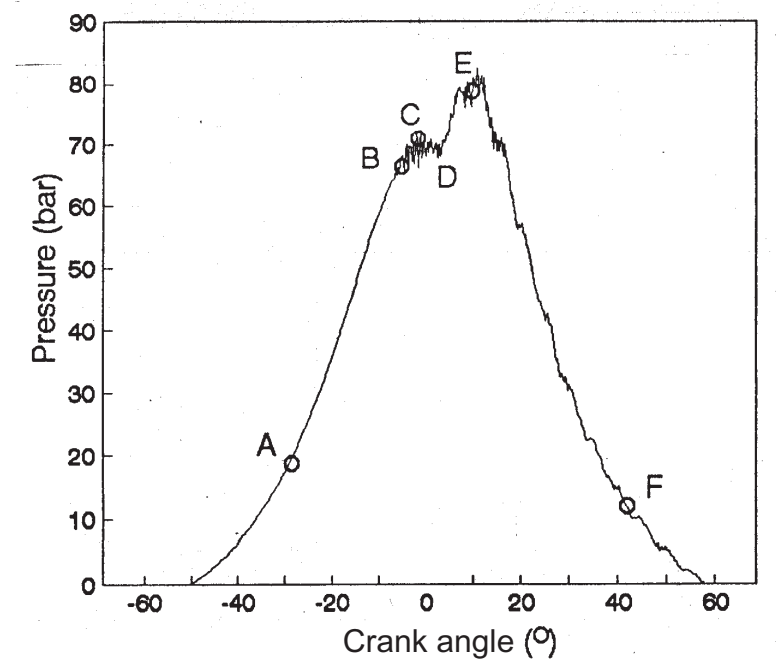

Figure 2. Dual fuel pilot injection pressure-crank angle diagram. 


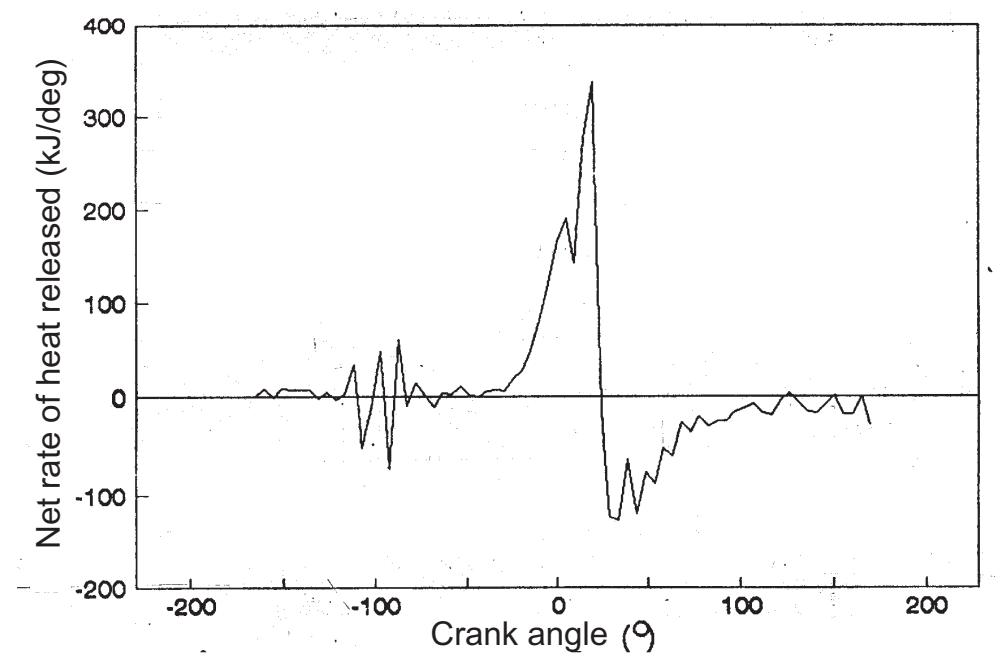

Figure 3. Dual fuel pilot injection heat release diagram (engine speed $=3600 \mathrm{rev} / \mathrm{min}$; engine torque output $=5.15 \mathrm{Nm}$ ).

those of CI and SI engines. It involves evolution of two stages of ignition and combustion processes resulting in three types of knock. The combustion processes in dual-fuel pilot injection system have been identified as taking place in five stages as shown in figure 2 . The phases are: the pilot ignition delay $(\mathrm{AB})$, pilot premixed combustion $(\mathrm{BC})$, primary fuel delay period (CD), rapid combustion of primary fuel (DE) and the diffusion combustion stage (EF). Figure 3 depicts low heat release rate due to combustion of pilot fuel (BC) and high heat release rate for the combustion of primary fuel (DE).

\subsection{Combustion knock in dual-fuel engine}

3.2a Diesel knock in dual-fuel engine: Diesel engines are generally noisy and knock occurs at all operating conditions especially when the engine is cold. The knock referred to in this scheme of work is an objectionable knock characterised by high pitch metallic sound. Figure 4 shows pure diesel fuel operation and can be compared with figure 2 showing dualfuel operation. The ripples in figure 2 are absent in figure 4, and are a result of combustion knock. Dual-fuel operation showed longer ignition delay as measured by the author. The start of combustion before top dead centre (TDC) when running on pure diesel fuel was $10.8^{\circ}$ as against $5.8^{\circ}$ for dual-fuel operation. Since the fuel metering system continues to inject fuel throughout the delay period, it was then thought that in dual-fuel systems, large quantities of premixed fuel would be involved when ignition eventually occurs. In an oxygen $\left(\mathrm{O}_{2}\right)$ depleted environment, it was thought that only a small quantity of pilot fuel reacts with $\mathrm{O}_{2}$ before autoignition of the mixture. The degree of knock in this phase was noted to depend on the ratio of the alternative fuel (natural gas) to the pilot fuel as shown in table 1 . This ratio is seen to depend on the load and speed of operation. It is a known fact that increase in speed increases the ignition delay when running on pure diesel fuel, hence the quantity of premixed pilot fuel that takes part in combustion increases. The pressure rise due to ignition of pilot fuel is also evident in the heat release diagram. This pressure rise viewed on the oscilloscope screen was lower than the maximum peak shown. 

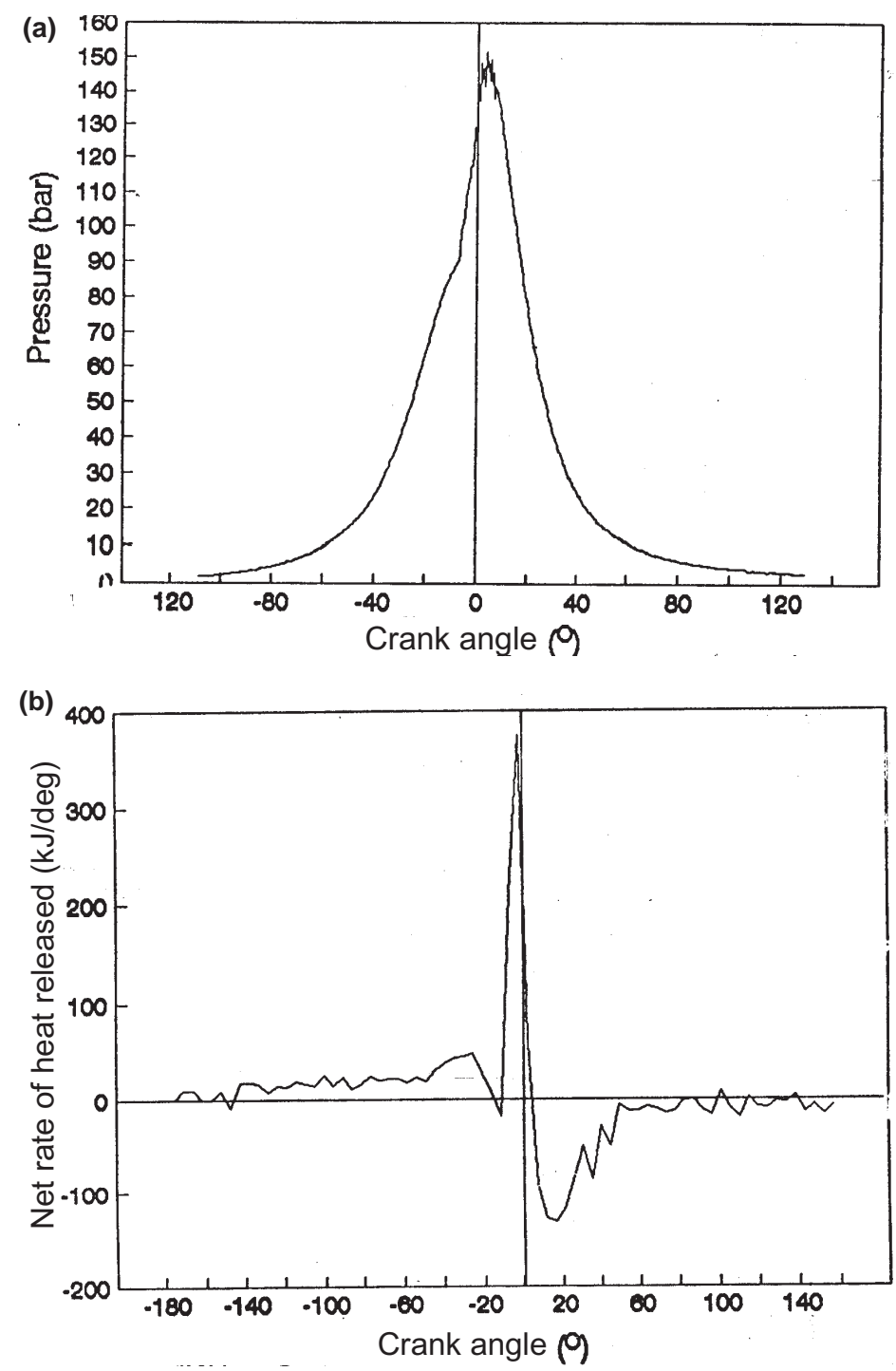

Figure 4. (a) Pressure-crank angle diagram of diesel fuel operation. (b) Heat released diagram of diesel fuel operation. (Engine speed $=3000 \mathrm{vev} / \mathrm{min}$; engine torque output $=9.65 \mathrm{Nm}$.)

3.2b Spark knock in dual-fuel engine: Knocking combustion in SI engine has been identified to be due to autoignition of the end gas. When autoignition occurs during normal combustion, the phenomena is called "spark knock". When knock occurs, high frequency pressure fluctuations are observed whose amplitude decays with time. These pressure fluctuations produce the sharp metallic noise called knock. The pressure distribution across the combustion chamber varies as measured by the transducer fitted in the combustion chamber and can be observed on the digital oscilloscope screen. In a dual-fuel engine, ignition occurs at different points in the chamber after the delay period unlike the single point ignition process of an SI engine. It involves two stages of ignition and combustion processes. The first combustion is due to autoignition of the pilot fuel, and then there is a finite time interval, as shown in figure 2 
Table 1. Effect of pilot fuel/gas ratio on knock characteristics of dual-fuel engine. Engine speed $=3000 \mathrm{rev} / \mathrm{min}$..

\begin{tabular}{lcccccc}
\hline $\begin{array}{l}\text { Load } \\
(\mathrm{N})\end{array}$ & $\begin{array}{c}\text { Pilot fuel } \\
(\mathrm{kg} / \mathrm{h})\end{array}$ & $\begin{array}{c}\text { Gas supply } \\
(\mathrm{kg} / \mathrm{h})\end{array}$ & $\begin{array}{c}\text { Total fuel } \\
(\mathrm{kg} / \mathrm{h})\end{array}$ & $\begin{array}{c}\text { \% Pilot } \\
\text { fuel }\end{array}$ & $\begin{array}{c}\text { \% Gas } \\
\text { supply }\end{array}$ & $\begin{array}{c}\text { Mixture } \\
\text { strength }\end{array}$ \\
\hline 6.61 & 0.305 & 0.626 & 0.931 & 32.76 & 67.24 & 0.557 \\
13.18 & 0.292 & 0.720 & 1.012 & 28.85 & 71.15 & 0.620 \\
17.72 & 0.271 & 0.792 & 1.063 & 25.49 & 74.51 & 0.667 \\
23.78 & 0.295 & 0.846 & 1.141 & 25.85 & 74.15 & 0.730 \\
28.82 & 0.313 & 0.882 & 1.195 & 26.19 & 73.81 & 0.779 \\
33.87 & 0.331 & 0.907 & 1.238 & 26.74 & 73.26 & 0.823 \\
38.92 & 0.343 & 0.936 & 1.279 & 26.82 & 73.18 & 0.866 \\
44.47 & 0.307 & 1.008 & 1.315 & 23.35 & 76.65 & 0.922 \\
\hline
\end{tabular}

(CD), for the second combustion to commence. This finite time is sufficient for heat transfer to the end gas to take place which increases the end gas pressure, temperature and reaction rate. These processes are influenced by the combustion chamber design and the level of turbulence in the cylinder. The dual-fuel operation is characterised by pressure fluctuations especially at low load levels where the delay period is seen to be longer. This fluctuation is reduced at high load and temperature due perhaps to the reduction in delay period and improved combustion at these operating conditions. The autoignition of a gaseous fuel-air mixture occurs when the energy released by the reaction as heat is larger than the heat lost to the surroundings. The temperature of the mixture therefore increases, which in turn increases the rates of reaction until self-ignition temperature (SIT) is reached. The degree of spark knock in dual-fuel engine also depends on the time interval between the first and second ignition. It is seen to decrease with increased load and combustion temperature. This is contrary to the knock in SI engines which increases with increased combustion temperature. The reason for this perhaps is the reduced delay period, a result of high combustion temperature.

3.2c Erratic knock in dual-fuel engine: The erratic knock phenomena of dual-fuel engine stems from two points. First, it is due to increasing quantity of alternative fuel taking part in the combustion process. Second, it depends on the operating conditions such as engine load, speed, temperature and oxygen concentration prevailing at the time of combustion. The pressure crank angle diagram of normal dual-fuel (figure 5) shows only the average peak pressure rise due to combustion of the alternative fuel. The peak pressure due to the pilot fuel, visible and lower than the latter (although difficult to capture on the screen), occurs much earlier than was photographed as the peak pressure under normal dual-fuel operation. This varying pressure has a contributory effect on the rough running of the engine. The increasing substitution of alternative fuel for diesel fuel results in severe knock. The pressure crank angle diagram (figure 6) obtained at the knock-limited point shows reduced peak cylinder pressure compared to those in figures 4 and 5. It has the longest ignition delay as measured and ignition of pilot fuel starts late in the expansion stroke. The knock-limit is established through enrichment of alternative fuel. The amplitude of the pressure fluctuations (erratic running) scores the cylinder liner. The oxygen concentration is perhaps one of the critical factors in the smooth running of dual-fuel engines. In the gas-fumigated dual-fuel engine, alternative fuel is in part substituted for the air thus reducing the oxygen concentration. Oxygen supplied to the intake system improved combustion through increased flame temperature and burning rate. The combustion process is also improved by increasing the quantity of pilot fuel and reducing the primary fuel especially when operating at low load conditions. 


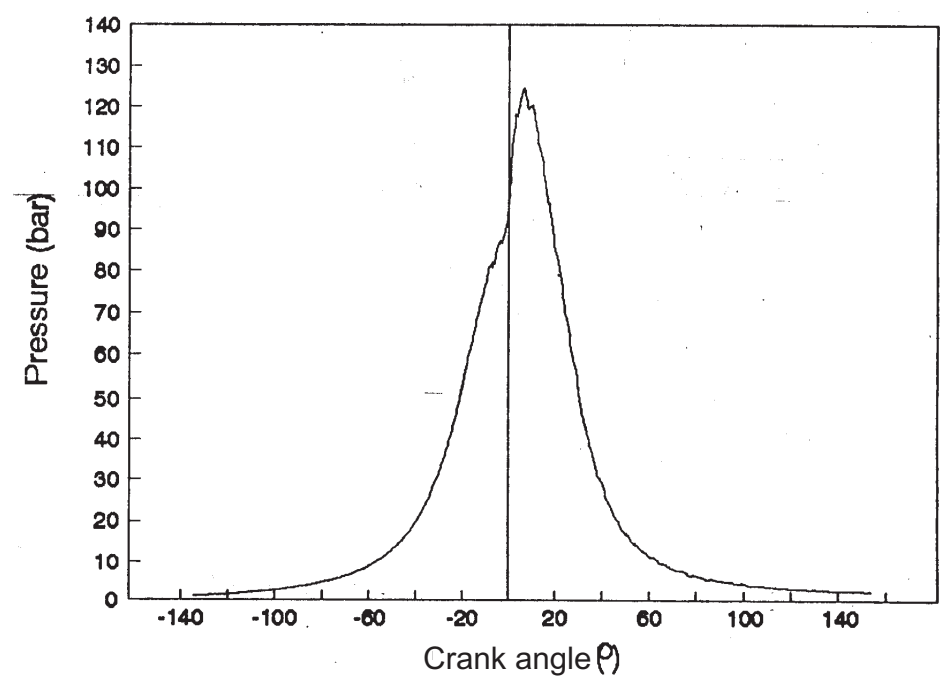

Figure 5. Normal dual pressure-crank angle diagram at $3000 \mathrm{rev} / \mathrm{min}$, and at engine torque of $9.65 \mathrm{Nm}$.

\subsection{Effect of operating speed on dual-fuel engine}

The effects of operating speed are two-fold. First, it affects the ignition delay, and second, it has greater influence on the smoke level. The measured ignition BTDC when running at $2400 \mathrm{rev} / \mathrm{min}$ and engine torque of $7.4 \mathrm{Nm}$ was $10.5^{\circ}$ for pure diesel fuel operation and $4.6^{\circ}$ for normal dual-fuel operation. Similar analysis made at $3000 \mathrm{rev} / \mathrm{min}$ and engine torque of 7.27 Nm gave the values of ignition BTDC as $5.8^{\circ}$ and $7.2^{\circ}$ for pure diesel and normal dual-fuel operation respectively. In general, the diesel fuel operation indicated that ignition delay increases with increased speed whereas the dual-fuel operation showed that the delay period was shortened with increased speed. It is therefore evident that gas-fumigated dual-

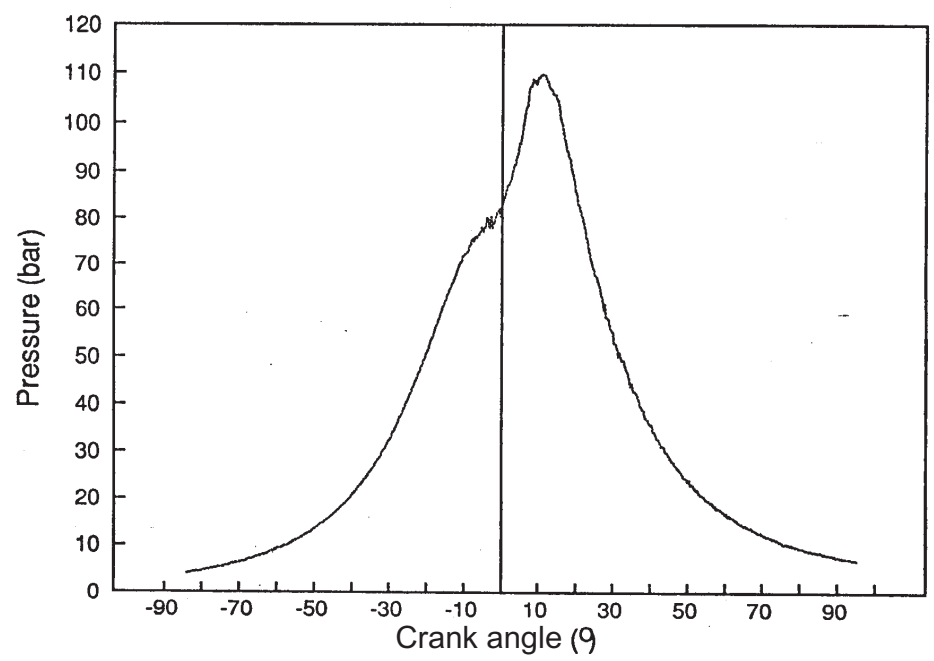

Figure 6. Knock-limit pressure-crank angle diagram at $3000 \mathrm{rev} / \mathrm{min}$ and at engine torque of $9.65 \mathrm{Nm}$. 
fuel engines require greater injection advanced at low speed to operate satisfactorily. The maximum engine torque obtained for both diesel fuel and normal dual-fuel operations at the speed of $2400 \mathrm{rev} / \mathrm{min}$ was $11.28 \mathrm{Nm}$ before the onset of smoke. Similar comparisons made at $3000 \mathrm{rev} / \mathrm{min}$ gave maximum torque of $12.28 \mathrm{Nm}$ for both fuels before the onset of smoke. These results clearly demonstrate that dual-fuel engines have lower smoke levels at low engine speeds.

\section{Conclusions}

Natural gas is fumigated during the induction stroke and some quantity of pilot diesel fuel is injected for the purpose of initiating combustion. In the gas-fumigated dual-fuel engine, the combustion processes are seen to lie between those of CI and SI engines, leading to five stages of combustion phases, unlike the four combustion stages of pure diesel fuel operation. It involves an evolution of two stages of ignition and combustion processes respectively. The ignition delay of the dual-fuel engine increases with decrease in engine speed, in contrast to pure diesel fuel operation. The cylinder pressure crank angle and heat release diagrams indicate that dual-fuel operations exhibit longer ignition delay and slower burning rates. Maximum peak cylinder pressure is reduced and the initial rate of pressure rise is low compared to diesel fuel operation. The power output of the dual-fuel operation is less compared to diesel fuel test results. In dual-fuel engines, three types of knock were identified. There are diesel knock due to combustion of premixed pilot fuel, spark knock due to autoignition of end gas, and erratic knock due to secondary ignition of the alternative fuel. The main factors that influence the occurrence of these knock are the pilot quantity, delay period, load, speed, gas flow rate and time interval for secondary ignition. Increasing the pilot fuel and reducing primary fuel reduces the knocking phenomena in dual-fuel engines.

\section{References}

Goodger E M 1980 Alternative fuels chemical energy resources (London: Macmillan)

Heywood J B 1988 Internal combustion engine fundamentals (New York: McGraw Hill)

Karim G A, Ali A I 1975 Combustion, knock and emission characteristics of a natural gas fuelled spark ignition engine with particular reference to low intake temperature conditions. Proc. IMechE 189: 139

Lowe W, Brandham P T 1971 Development and application of medium speed gas burning engines. Proc. IMechE 186: 72

Moore N P W, Mitchell R W S 1955 Combustion in dual-fuel engines. Proc. IMechE : 330

Needham J B, Doyle D M 1983 The combustion and ignition quality of alternative fuels in light duty diesels. SAE 852101, p 1

Nwafor O M I 2000 Effect of advanced injection timing on the performance of natural gas in diesel engines. Sädhanā 25: 11-20

Nwafor O M I, Rice G 1994 The combustion characteristics and performance of natural gas in a high speed indirect injection diesel engines. Proc. World Renewable Energy Congress, UK, vol 2, p 841

Stephenson J, Raine R R 1980 The use of producer gas in diesel engine. (Am. Soc. Agric. Eng.) ASAE p 48.1

Stone C R, Ladommatos N 1991 Design and evaluation of a fast burn spark ignition combustion system for gaseous fuels at high compression ratios. J. Inst. Energy 64: 202 